Ann. Biol. anim. Bioch. Biophys., 1977, 17 (6), 1095-1099.

\title{
Plasma prolactin variations in the male calf in relation to age, season and breed
}

\author{
par A. LACROIX, J. P. RAVAULT *, J. PELLETIER \\ Station de Physiologie de la Reproduction, I. N. R. A. \\ Nouzilly 37380 Monnaie, France. \\ * Faculté des Sciences, Laboratoire de Physiologie Comparée \\ Parc Grandmont, 37200 Tours, France.
}

\begin{abstract}
Summary. Plasma prolactin levels have been measured by radioimmunoassay in 42 calves collected from birth till one year of age. The calves belonged to five breeds : Française-Frisonne-Pie-Noire, Charolais, Limousin, Maine-Anjou and Hereford. Prolactin levels varied according to daylength $(r=0.89)$, and were influenced by photoperiod as early as one month of age. Mean annual level of prolactin did not differ between breeds (min. value in Frisonne : $8.3 \pm 0.4 \mathrm{ng} / \mathrm{ml} ; \max$. value in Limousin : $10.7 \pm 1.4 \mathrm{ng} / \mathrm{ml}$ ) or according to age.
\end{abstract}

\section{Introduction.}

In domestic mammals, the release of prolactin by the adult male pituitary, has recently been studied in sheep (Pelletier, 1973 ; Ravault, 1976), goats (Buttle, 1974) and cattle (Karg and Schams, 1974). A dramatic increase, then a decrease in blood prolactin occurs when photoperiod varies from short to long days and conversely. In the prepubertal male, little is known, except the data from Ravault and Courot (1975) in the lamb, and that of Schams and Reinhardt (1974) in the calf showing that blood prolactin levels varied with daylength from birth to adulthood. In the present study, we have examined plasma level variations of this hormone in relation to age and daylength in 42 male calves from five breeds during the first year of life.

\section{Material and methods.}

1. Animals. The 42 male calves were born in the same year between 24 January and 5 May 1974. They were divided into five groups according to breed : Charolais $(\mathrm{CH} ; n=16)$, Hereford (He ; $=7$ ), Maine-Anjou (MA ; $=5)$, Limousin ( $\mathrm{Li}$; $n=4$ ), Française-Frisonne-Pie-Noire (FFPN; $n=10$ ). All animals were kept under the same conditions of management and nutrition during the experiment. 
2. Blood samples. Blood was collected from the jugular vein before feeding at 9.00 AM, once per week from one week after birth until six months of age, and then every other week until all animals were 12 months old.

After centrifugation plasmas, were stored at $-15^{\circ} \mathrm{C}$ until they were analysed for prolactin concentration.

3. Assay. A specific double antibody radioimmunoassay described by Kann (1971) for ovin prolactin was used for bovine prolactin. We have verified that bovine plasma dilutions gave results similar to the ovine standard. Results are expressed in $\mathrm{ng}$ NIH-PS6 per $\mathrm{ml}$ of plasma.

\section{Results.}

1. Plasma prolactin levels in different breeds. The mean annual level of plasma prolactin was evaluated for each animal and ranged between $8.3 \pm 0.4$ and $10.7 \pm$ $1.4 \mathrm{ng} / \mathrm{ml}$, depending on the breed (FFPN and $\mathrm{Li}$, respectively) (table I) ; there were no significant differences between the five breeds. Similarly, no difference was apparent corresponding to seasonal variations and age. For example, mean monthly prolactin levels were minimal in late fall or early winter $(1.7$ to $2.7 \mathrm{ng} / \mathrm{ml})$ according to breed, while they were maximal in early summer $(13.0-17.0 \mathrm{ng} / \mathrm{ml})$. The magnitude of change in plasma prolactin level during seasonal variations was about fivefold in all groups.

Thus, the data from all breeds were pooled for subsequent analysis according to the month of sampling.

\section{TABLE 1}

Mean annual prolactin levels in five different calf breeds

\begin{tabular}{cccccc}
\hline & $\mathrm{CH}$ & $\mathrm{He}$ & $\mathrm{MA}$ & $\mathrm{Li}$ & $\mathrm{FFPN}$ \\
$\mathrm{m}$ & 9.8 & 9.6 & 9.3 & 10.7 & 8.3 \\
\hline $\mathrm{SEM}$ & 0.8 & 0.6 & 1.2 & 1.4 & 0.4 \\
\hline $\mathrm{n}$ & 16 & 7 & 5 & 4 & 10 \\
\hline
\end{tabular}

( $n=$ number of animals of each breed sampled during the first year of life).

2. Effect of daylength on plasma prolactin levels. The monthly pooled prolactin levels followed the annual variations of daylight length $(r=+0.89 ; P<0.001)$ (fig. 1). Prolactin levels increased from November to July and regressed from July to November. The lowest and highest levels found in November and July were, respectively : $3.3+0.5$ and $15.5 \pm 0.8 \mathrm{ng} / \mathrm{ml}$.

The same plasma prolactin levels were observed at birth whatever the month (about $5 \mathrm{ng} / \mathrm{ml}$ ). However, in winter-born animals the level decreased to $3.2 \pm 0.9 \mathrm{ng} / \mathrm{ml}$ 
at one month of age while at the same time the prolactin levels increased up to $7.1 \pm 0.2 \mathrm{ng} / \mathrm{ml}$ and $9.6 \pm 0.9 \mathrm{ng} / \mathrm{ml}$ in calves born in March and April, respectively. The difference in prolactin levels at one month of age in winter and spring-born animals is highly significant (fig. $2 ; P<0.001$ ) and even in March and April-born calves $(P<0.02)$.

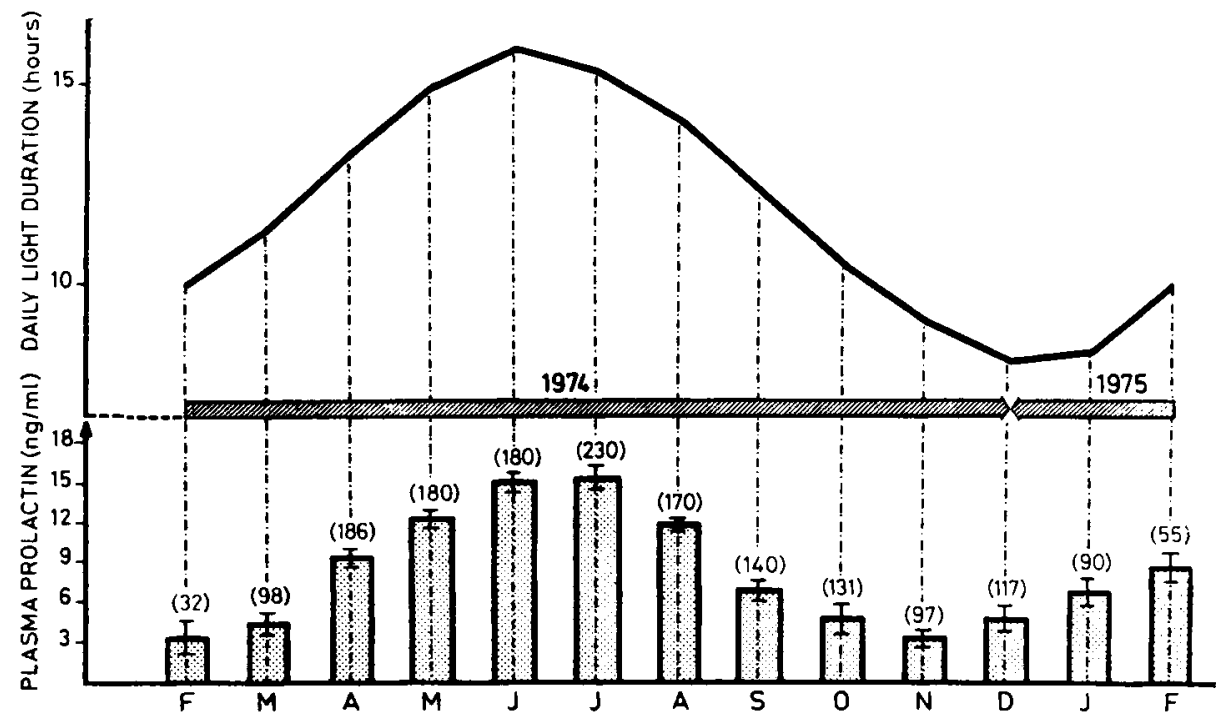

FIG. 1. - Seasonal variations in plasma prolactin in calves (mean $\pm S E M) .(\quad)=$ number of monthly bloold samples assayed.

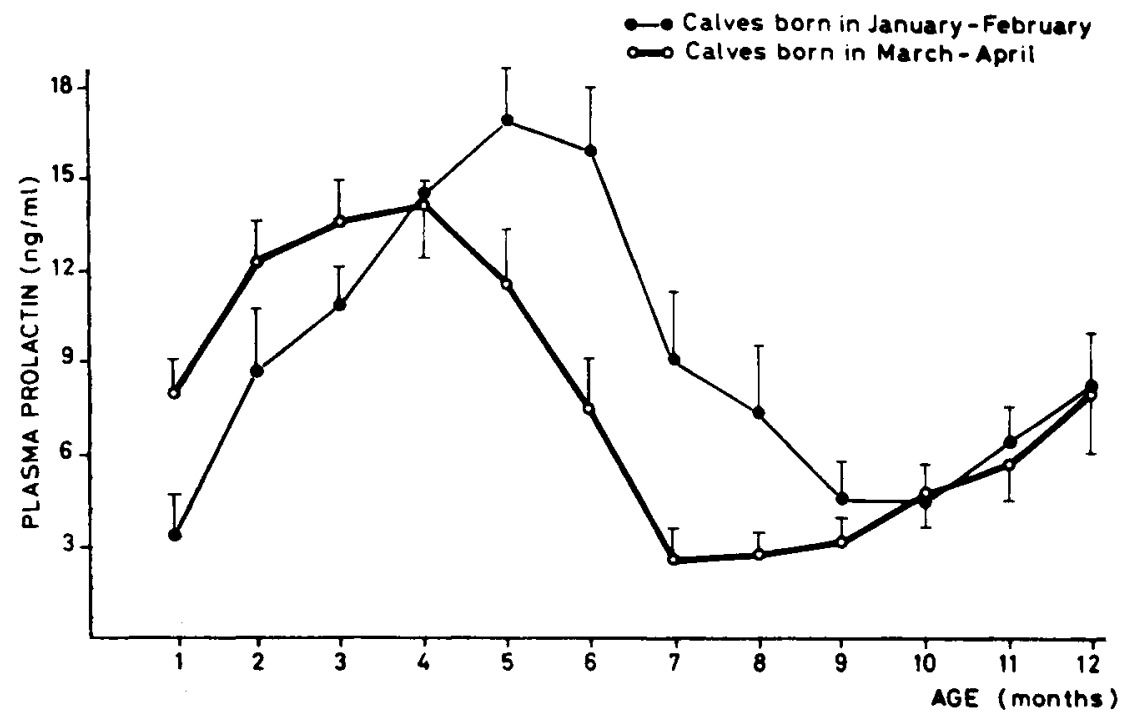

FIG. 2. - Seasonal variations in plasma prolactin in calves born in winter or in spring 1974. Each point represents the pooled value of four weekly bleedings. 
At one year of age, plasma prolactin levels were not significantly different from those observed at birth and thus between birth and one year, daylength regulated prolactin levels as in adult.

\section{Discussion.}

The pattern of plasma prolactin during the first year of life does not seem to be particularly related to age. Prolactin level at one year of age is roughly similar to that found at birth. These results agree with those of Schams and Reinhardt (1974), showing that the annual pattern in prolactin release is practically identical during the first and the second year of life ; the present data do not show evidence of significant breed differences in prolactin release. Finally, in our 42 calves, prolactin levels are positively correlated with daylight length. These results confirm those of Schams and Reinhardt (1974) and Bourne and Tucker (1975) obtained in a few bull calves. It appears from fig. 2 that prolactin light control occurs very rapidly after birth.

Differences between calf and lamb must be pointed out. Although levels are also higher in the latter in July, maximum blood concentrations reach a mean level of about $90 \mathrm{ng} / \mathrm{ml}$ (vs $14 \mathrm{ng} / \mathrm{ml}$ in the calf); an acute increase occurs in the lamb at about 12 weeks after birth (Ravault and Courot, 1975 ; Ravault, 1976). In the bull calf, the absence of such a peak at the time of puberty, and the adult-type prolactin levels observed immediately after birth, do not allow speculation on the role of prolactin in the prepubertal period.

Reçu en juillet 1977.

Accepté en septembre 1977.

Acknowledgements. - We thank Dr. G. Kann and the National Institute of Health Hormone Distribution Program for providing reagents used in radioimmunoassay and Dr. F. Menissier for help in collecting blood samples. Expert technical assistance was due to A. Caraty.

Résumé. Le taux de prolactine plasmatique a été mesuré par radioimmunologie chez 42 veaux depuis la naissance jusqu'à l'âge d'un an. Ces animaux collectés une fois par semaine puis tous les quinze jours au-delà de six mois appartenaient aux cinq races suivantes : Française-Frisonne-Pie-Noire, Charolaise, Limousine, Maine-Anjou ef Hereford. Le taux de prolactine s'accroît avec la durée de la photopériode claire et vice versa ; le coefficient de corrélation entre ces deux paramètres au cours de l'année est $r=+0,89$. L'influence de la photopériode s'exerce dès le premier mois qui suit la naissance, comme le montrent les niveaux de prolactine différents dès le premier mois, selon la période de l'année où a lieu la naissance. En revanche, la moyenne annuelle du taux de prolactine ne diffère pas significativement entre les races (taux annuel minimum chez les veaux Frisons : $8,3 \pm 0,4 \mathrm{ng} / \mathrm{ml}$, taux annuel maximum chez les limousins : 10,7 $\pm 1,4 \mathrm{ng} / \mathrm{ml}$ ), $\mathrm{ni}$ en fonction de l'ầge. 


\section{References}

BOURNE R. A., TUCKER H. A., 1975. Serum prolactin and LH responses to photoperiod in bull calves. Endocrinology, 97, 473-475.

BUTTLE H. L., 1974. Seasonal variations of prolactin in plasma of male goats. J. Reprod. Ferf., 37, 95-99.

KANN G., 1971. Dosage radio-immunologique de la prolactine plasmatique chez les ovins. $C$. $R$. Acad. Sci. Paris, Sér. D., 272, 2808-2811.

KARG H., SCHAMS D., 1974. Prolactin release in cattle. J. Reprod. Fert., 39, 463-472.

PELLETIER J., 1973. Evidence for photoperiodic control of prolactin release in rams. J. Reprod. Ferf. 35, 143-147.

RAVAULT J. P., 1976. Prolactin in the ram : seasonal variations in the concentration of blood plasma from birth until three years old. Acto. endocr., 83, 720-725.

RAVAULT J. P., COUROT M., 1975. Blood prolactin in the male lamb from birth to puberty. J. Reprod. Fert., 42, 563-566.

SCHAMS D., REINHARDT V., 1974. Influence of the season on plasma prolactin level in cattle from birth to maturity. Horm. Res., 5, 217-226. 